\title{
透明導電膜（ITO）のプロセスと膜特性
}

\author{
新 井真
}

(株)アルバック 超材料研究所（～253-8543 神奈川県茅ケ崎市萩園 2500）

\section{Process and Film Properties of Transparent Conductive Oxide (ITO)}

\section{Makoto ARAI}

Institute for Super Materials, ULVAC Inc.(2500, Hagisono, Chigasaki-shi, Kanagawa 253-8543)

Keywords : Transparent Conductive Oxide (Film), Sputtering, ITO

\section{1.はじめに}

透明導電膜は, ディスプレイ, タッチパネル, 太陽電池な どの幅広い分野で使用され，全ての分野に共通して高透過か つ低抵抗な性能が求められる。また，製造の観点から，低コ ストで安定生産を可能にする材料が求められている。ディス プレイの傾向としては, 高精細, 低消費電力が差別化のキー ワードになっており，最新の携帯端末では 300 ppi 以上の高 精細なディスプレイを搭載する機種が増えている。このため, 透明導電膜には，パターニングの容易性と光損失を低減させ るための高透過特性が必須である。

現在，ディスプレイに多く使用されている透明酸化物薄膜 材料は, 酸化スズドープ酸化インジウム $\left(\mathrm{In}_{2} \mathrm{O}_{3}-\mathrm{SnO}_{2}\right.$, 通称 : ITO)である。In は希少金属で高価ではあるが, ITO は現在 知られている透明導電膜の中では最も抵抗が低く, 成膜条件 も容易に実現できるものであるため, 広い分野で使用されて いる。ITO の代替材料も多く研究されているが，成膜条件が 困難なことや大型化が困難などの課題があるため, 生産へ移 行できているものは限られている。

本稿では，ITOのスパッタリング法による成膜パラメータ の影響と, ITO ターゲットへの添加物による ITO 膜への影 響に関して解説する。

\section{2. 透明導電膜の成膜方法}

透明導電膜の作製方法には，スプレー法，塗布法，CVD (Chemical Vapor Deposition) 法などの化学的作製法と, 真空 蒸着法, スパッ夕法などの物理的作製方法に分類することが できる。

化学的作製方法は, 塩化物の加水分解や有機化合物の熱分 解反応により酸化物半導体薄膜を作製する方法で，工程が簡 単で装置が安価というメリットがある。しかしながら，通常 $400{ }^{\circ} \mathrm{C}$ 程度の反応温度を必要とするため, 耐熱性の低い基板 への適用が困難であること, 化学量論組成から少し還元気味 にすることで酸素空孔などの真性欠陥がドナー準位を形成し 電気伝導性を持つ酸化物半導体材料では組成の最適化が困難
であること，有害ガスを発生することなどの問題がある。一 方, 物理的作製方法は, 成膜中に真空䨌囲気への導入酸素量 を調整することにより，組成の最適化が可能であること，耐 熱性の低い CF (Color Filter) 基板や TFT（Thin Film Transistor） 素子，フィルム基板などへの適用が可能であることなどのメ リットを持つ。そのため, LCD (Liquid Crystal Display)をア プリケーションとした透明導電膜の作製では, 主に真空蒸着 法やスパッ夕法が採用されている。特にスパッ夕法は真空蒸 着法に比べ大型基板への均一成膜や膜特性の制御に優れてお り，本節ではスパッ夕法を中心とした透明導電膜の作製方法 を扱う。

\section{1 成膜パラメータ}

酸化物半導体薄膜を作製する際の主なパラメータには，酸 素導入量, 不純物添加量, 成膜温度, スパッ夕電圧があり, それぞれのパラメータの特徵を ITO 中心に説明する。

\section{1.1 酸素導入量}

酸化物半導体薄膜材料は化学量論組成から少し還元気味に することで酸素空孔などの真性欠陥がドナー準位を形成し電 気伝導性を持つため, 薄膜の組成を最適化するためには酸素 導入量のコントロールが重要なパラメータとなる。

ITO の場合, 酸素導入量の増加に伴い化学量論組成の $\mathrm{In}_{2} \mathrm{O}_{3}$ に近づくため結晶格子が整い移動度の向上が見られる が, 酸素空孔による自由電子の放出が低減し, さらに酸素過 多な領域では, $\mathrm{In}^{3+}$ 置換している $\mathrm{Sn}^{4+}$ が酸化しキャリア密 度が低下するため, 適切な酸素導入量をコントロールする必 要がある。

\section{1. 2 不純物添加量}

不純物半導体のドナーとして添加する不純物は，置換型で 結晶格子に入り込み自由電子を放出することで電気伝導性を 得るため, 置換型で結晶格子に入り込まない不純物は電気伝 導性に寄与せず，格子散乱などにより移動度が低下し逆に電 気伝導性を劣化させてしまう。特に $\mathrm{AZO}\left(\mathrm{ZnO}-\mathrm{Al}_{2} \mathrm{O}_{3}\right)$ の不純 物に用いている $\mathrm{Al}_{2} \mathrm{O}_{3}$ のような絶縁性の高い材料では，不純 物がイオン化せずに薄膜中に取り込まれた場合, 絶縁性の性 質が現れ電気伝導性が顕著に劣化する。当然, 置換型で結晶 
格子に入り込んだ不純物も，キャリア密度の増加に伴い，格 子散乱やイオン化した不純物から受けるクーロン力が及ぼす 不純物散乱により移動度が低下する方向となる。酸化物半導 体薄膜の作製方法により，不純物のイオン化率は異なるため, 酸化物半導体薄膜材料の不純物添加量を最適化する必要があ る。スパッ夕法においては, 生産性に優れる DC 放電が主に 用いられており, ターゲット自体も高い電気伝導性を持つ必 要があることから, $\mathrm{In}_{2} \mathrm{O}_{3}$ に $\mathrm{SnO}_{2}$ を 10 重量 \% 添加した焼結 体ターゲットが広く用いられている。

2. 1.3 成膜温度

成膜温度の上昇に伴い結晶性が向上し移動度が増加するこ と，㧍よび $\mathrm{Sn}^{4+}$ が $\mathrm{In}^{3+}$ を置換しキャリア密度が増加するこ とにより電気伝導度が高くなる。図 1, 図 2 の結晶化の成膜 温度依存性にガラス基板上に作製した無加熱成膜 ITO 薄膜 と $200{ }^{\circ} \mathrm{C}$ 成膜 ITO 薄膜の XRD (X 線回折, X-Ray Diffraction) 強度分布，および 50000 倍で観察した SEM（走查電子顕微鏡， Scanning Electron Microscope) 像を示す。加熱成膜した ITO 薄 膜においては, 複数の配向性を示すため鱗状の表面状態と なっている。種々の実験により, 低温で作製した非晶質 ITO 薄膜は酸素空孔による自由電子の放出が支配的であり, 高温 で作製した多結晶 ITO 薄膜は $\mathrm{Sn}^{4+} か ゙ \mathrm{In}^{3+}$ を置換し放出され た自由電子が支配的なドナーであると考えられる。

ITO 薄膜のウエットエッチングにおけるエッチング速度は, ITO 薄膜の結晶性に顕著に依存し， $150 \sim 200{ }^{\circ} \mathrm{C}$ 付近にある 結晶化温度の前後で大きく変化する。特に結晶化温度付近で は，非晶質と結晶質の混在した膜質になり，エッチング特性 が極めて不安定となるため, 低温で均一な非晶質薄膜を作製 するか， $200{ }^{\circ} \mathrm{C}$ 以上の高温で十分に結晶化させた薄膜を作製 する必要がある。成膜中のプラズマによる基板温度の上昇な どにより, 安定して非晶質な薄膜を得ることは困難であり，
この課題に対する対策は「3. 透明導電膜を応用したデバイス」 で述べることとする。

2. 1.4 スパッ夕電圧

石橋らにより，スパッタ法で ITO 薄膜を作製する際に, 負イオンによるプラズマダメージを低減させて, 従来よりも 大幅に低抵抗でエッチング速度の安定した ITO 薄膜を得る ことのできる, 低電圧スパッタ法(LVS, Low Voltage Sputter) が報告されている ${ }^{1,2)}$ 。低電圧スパッ夕法では，スパッ夕電 圧の低下に伴う ITO 薄膜の低抵抗化を負イオン入射による ダメージが低減したためと考察し，次の反応モデルを作製し ている。

$$
\text { イオン衝撃 } \mathrm{In}_{2} \mathrm{O}_{3} \Rightarrow 2 \mathrm{InO}+\mathrm{O}
$$

ITO の基本組成である $\mathrm{In}_{2} \mathrm{O}_{3}$ に高エネルギーの粒子が衝突 すると, 上記分解反応により薄膜中に黒色絶縁性の低級酸化 物である $\mathrm{InO}$ が生成され，その絶縁性からキャリア密度が 減少し，比抵抗が上昇する。つまり，低抵抗化において悪影 響となる薄膜に衝突する粒子のエネルギーを低下させるため, スパッ夕電圧を低下させ, 負イオンの電圧加速によるエネル ギー増加を抑制する技術である。低電圧スパッ夕法の開発に より, 従来の $-370 \mathrm{~V}$ から $-250 \mathrm{~V}$ 程度までスパッ夕電圧が 低下され, $200{ }^{\circ} \mathrm{C}$ 成膜で $200 \mu \Omega \cdot \mathrm{cm}$ 以下の低抵抗な ITO 薄 膜が実用レベルで作製可能となった。

\section{3. 透明導電膜を応用したデバイス}

透明導電膜は, FPD (Flat Panel Display), タッチパネル， 太陽電池, 電磁シールド, AR (Anti Reflection) 膜, LED (Light Emitting Diode)などに広く応用されており, 特に FPD 関連で は, LCD (TN Twist Nematic, STN Super Twist Nematic, TFT, CF), OLED (Organic Light Emitting Diode), PDP (Plasma Display Panel), FED (Field Emission Display), 電子ペーパー
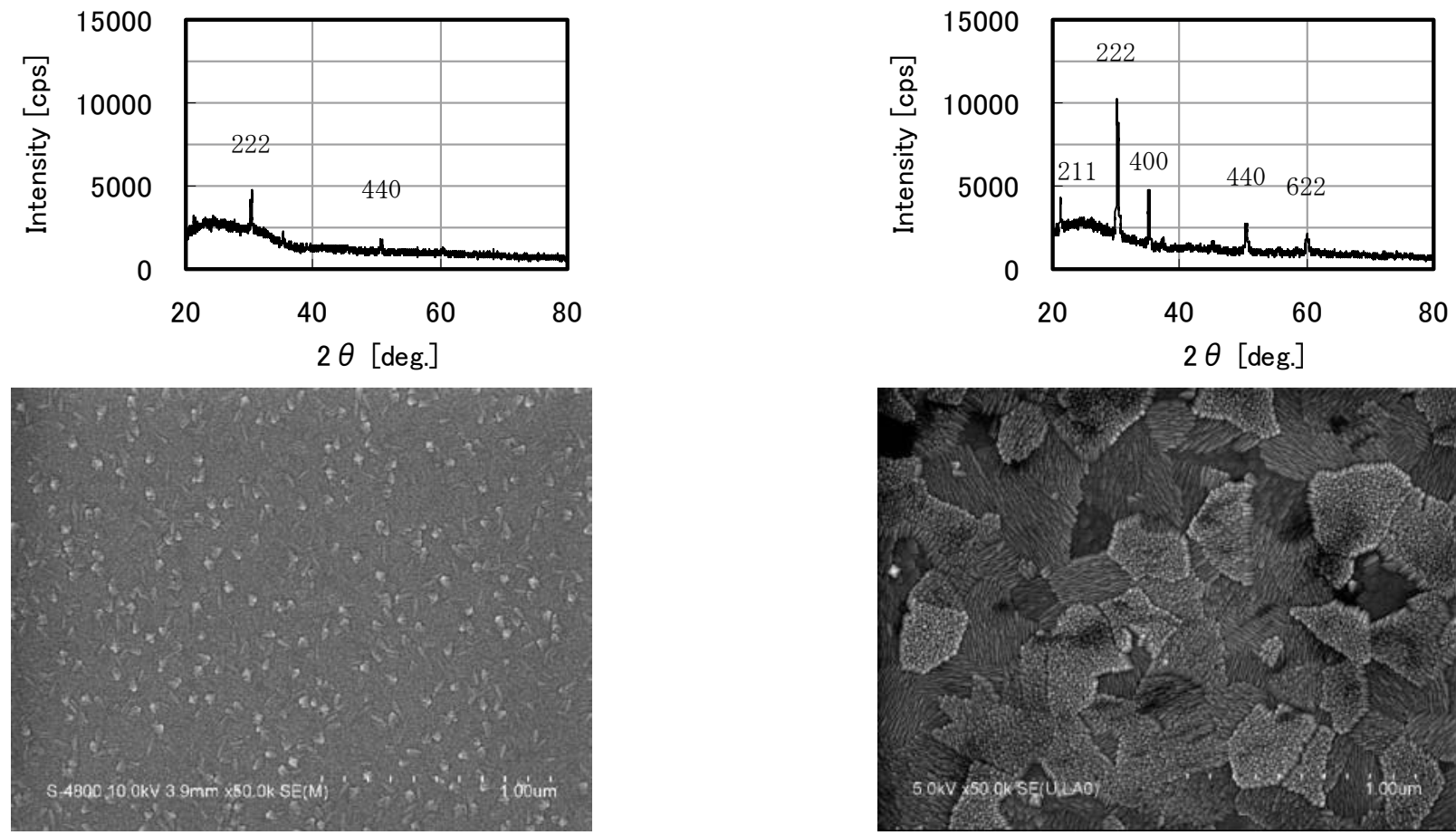

図 1 結晶化の成膜温度依存性 (無加熱成膜)

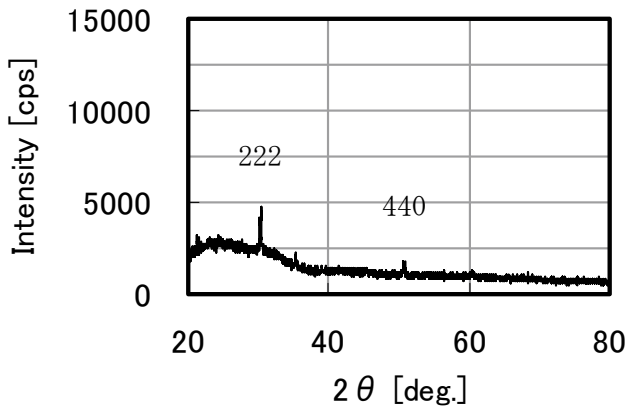

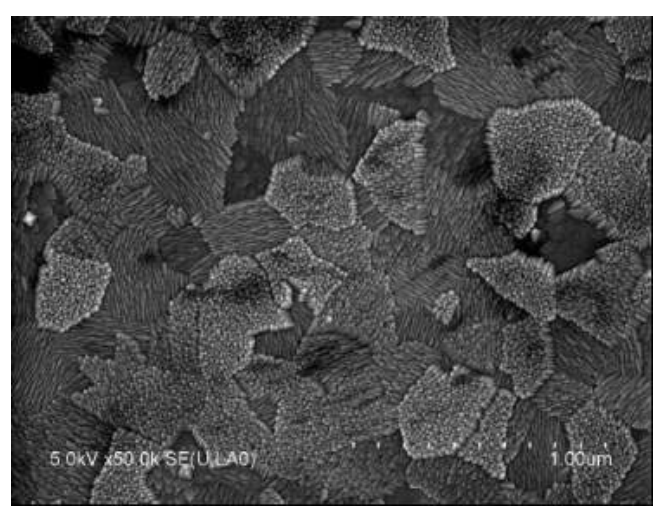

図 2 結晶化の成膜温度依存性 $\left(200{ }^{\circ} \mathrm{C}\right.$ 成膜 $)$ 
など様々なデバイスで使用されている。

\section{3. $1 \mathbf{H}_{2} \mathbf{O}$ ガス添加による効果}

TFT の画素電極のような素子で用いられる ITO 薄膜には, 回路パターニングの必要性から安定で加工性に優れたエッチ ング特性が要求される。石橋らはITO 薄膜作製時の $\mathrm{H}_{2} \mathrm{O}$ 分 圧が ITO 薄膜の結晶性に大きく影響することを見いだし， 一定量の $\mathrm{H}_{2} \mathrm{O}$ または $\mathrm{H}_{2}$ を添加し比抵抗とウェットエッチン
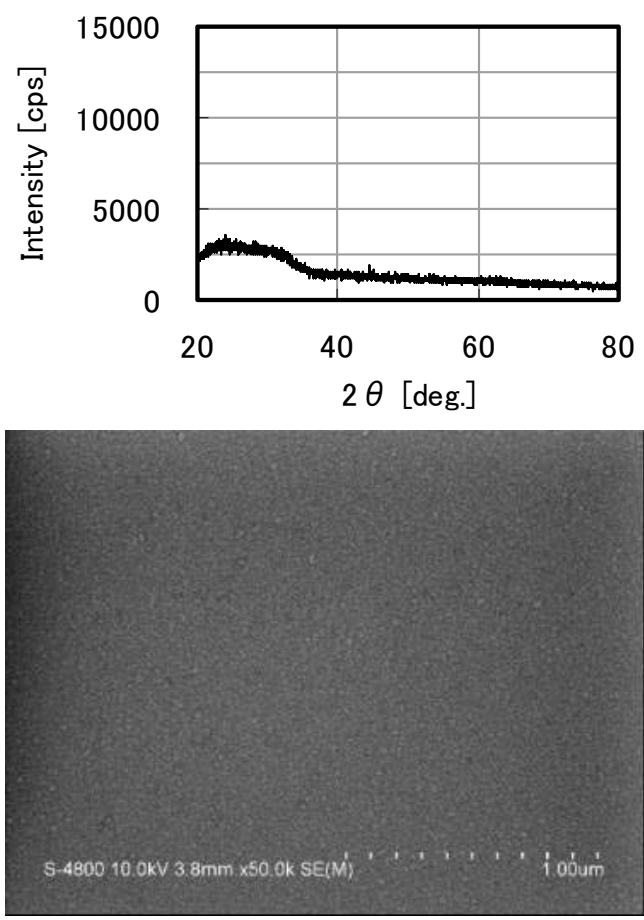

図 3 非晶質 ITO 成膜プロセスで作製した ITO 薄膜 の結晶性 (as-depo.)
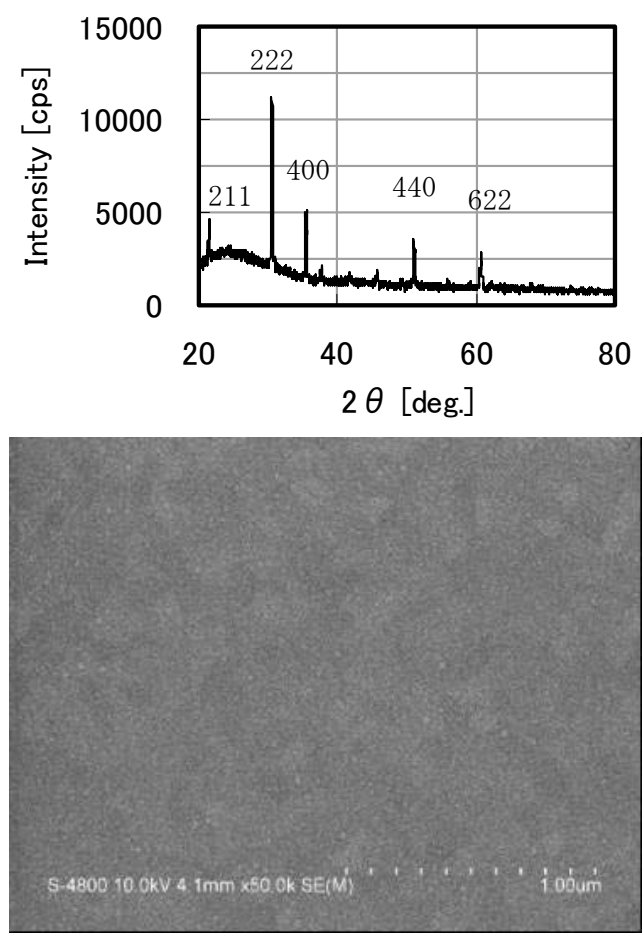

図 4 非晶質 ITO 成膜プロセスで作製した ITO 薄 膜の結晶性(熱処理後)
グの安定性に優れた非晶質 ITO 成膜プロセスを開発した ${ }^{3), 4)}$ 。 図 3, 図 4 に非晶質 ITO 成膜プロセスで作製された ITO 薄 膜の XRD 強度分布および50000 倍で観察した SEM 像 (asdepo., 熱処理後)を示す。非晶質 ITO 成膜プロセスで作製さ れた ITO 薄膜 (as-depo.) は, 図 1 の結晶化の成膜温度依存性 (無加熱成膜) と比較しても，より非晶質で表面粗さの小さい ITO 薄膜が得られていることがわかる。

非晶質 ITO 成膜プロセスで作製された ITO 薄膜でも，熱 処理を行えば結晶化が促進され, 移動度と耐薬品性が上がり， さらに $\mathrm{Sn}^{4+}$ が $\mathrm{In}^{3+}$ を置換することによりキャリア密度が増 加した低抵抗な特性を得ることができる。このことは, 非晶 質 ITO 成膜プロセスで得られた安定したウェットエッチン グ特性によりパターニング処理を行い，その後は熱処理によ り耐環境性に優れ低抵抗な ITO 薄膜を作製可能である。

\section{2 低温低抵抗 ITO 成膜技術}

3.1 で述べたように ITO 薄膜成膜時に $\mathrm{H}_{2} \mathrm{O}$ ガスを添加す ることで，非晶質 ITO を成膜することができ安定で加工性 の良いエッチング特性が得られる。しかし, 非晶質であるこ とから比抵抗はどうしても高くなってしまい透過率も低い值 となる。近年特にタッチパネル向けに $150{ }^{\circ} \mathrm{C}$ 程度以下の低温 領域においても, 結晶 ITO と同等程度の低抵抗, 透過率が 得られる成膜技術が求められており，非晶質 ITOではその 要求を満たすことはできない。湯川らは低温領域でも結晶化 し低抵抗, 高透過率な特性を示す ITO の成膜技術を開発し た ${ }^{5)}$ 。図 5 にITOに $\mathrm{O}_{2}$ ガスを添加した際のシート抵抗のデー 夕を示す。条件は従来方式の ITOに対し, ITOの組成およ び条件を変更した 3 条件 $(\mathrm{A}, \mathrm{B}, \mathrm{C})$ について, 膜厚 $10 \mathrm{~nm}$, プロセス温度 $150{ }^{\circ} \mathrm{C}$ で成膜, 評価を実施した。最適 $\mathrm{O}_{2}$ 流量 におけるシート抵抗の最小值は従来方式条件で $800 \Omega / \square$, ITO A で $420 \Omega / \square$, ITO B で $300 \Omega / \square な の に$ 対し, ITO C で $200 \Omega / \square か ゙$ 得られた。このうち，ITO A，B はすでに低 温低抵抗が求められるフィルム機材への成膜技術として量産 適用されているが, 湯川らは，それよりもさらに低抵抗化さ せることに成功した。

図 6 に各条件において成膜した薄膜のXRD デー夕を示す。 このデータから従来方式の ITO は結晶化を示すピークが見 られないため非晶質であるのに対し，ITO A， B， C は結晶

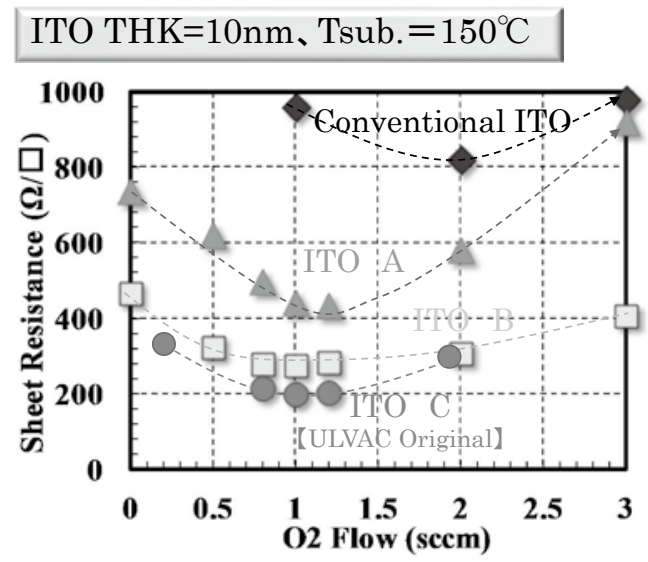

図 5 各種 ITO 成膜条件における $\mathrm{O}_{2}$ 添加に対して のシート抵抗挙動 


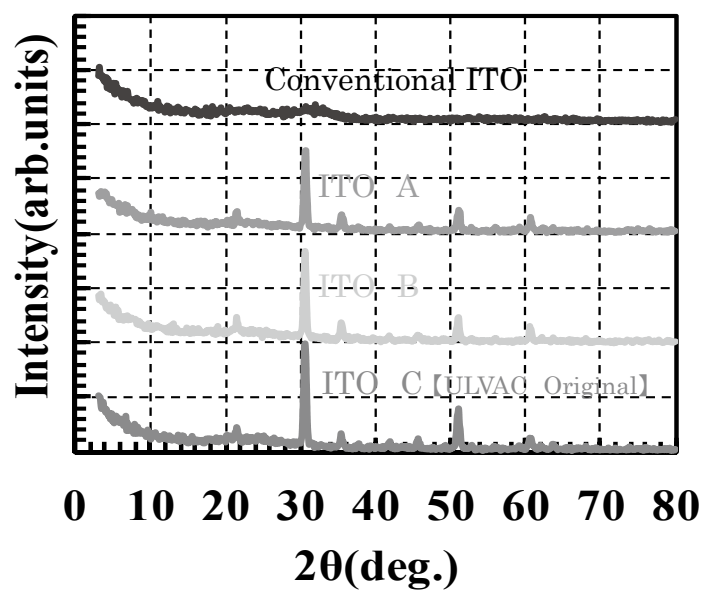

図 6 各種 ITO 成膜条件におけるXRD データ

化していることを示すピークが見られた。特に ITO C はピー ク強度が最も強い結果が得られた。このことから ITO C は より結晶化度合いが高いために低抵抗な特性が得られている ことが分かる。

図 7 に各条件において成膜した薄膜の透過率データを示す。 シート抵抗，XRDで示したように従来方式，ITO A と B, ITO C の順番に結晶化度合いが高くなっており，それにとも ない, 特に短波長側の透過率が高い数值を示している。以上 の結果より ITO C は今後低温低抵抗の要求に対して非常に 有望な技術と言える。

\section{4. おわりに}

本稿では, 生産機への応用という部分に着目して，スパッ タリング法によるITO 成膜について概括した。製品をコス トダウンしていく上では, 生産性の向上や ITO 薄膜加工の 容易性は重要な要因であり, より一層の工夫が求められてい く。今後のディスプレイ, タッチパネルの分野でITO の役 割としては, 高透過性, 低抵抗, 成膜温度の低温化が求めら れる。そのため, 透明導電膜の薄膜化, 低温での結晶化など

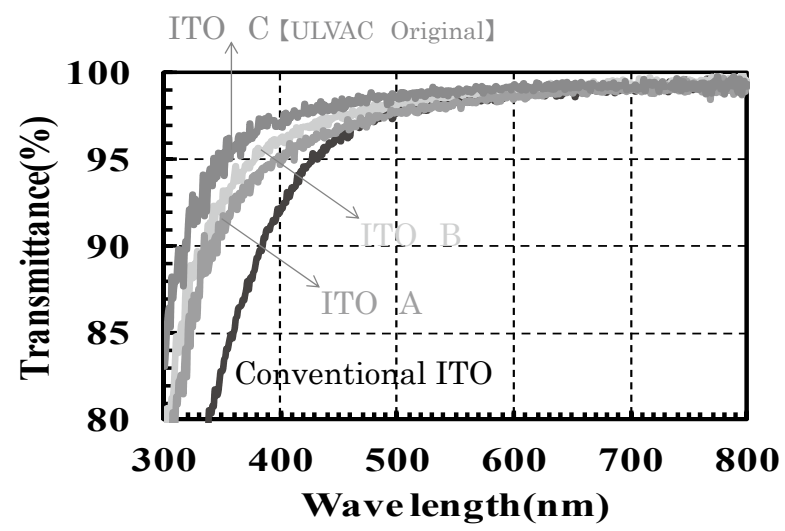

図 7 各種 ITO 成膜条件における $\mathrm{O}_{2}$ 添加に対してのシート抵 抗挙動

の特性が新たに必要であり, 要求はさらに厳しくなってきて いる。ITO の高品質化も課題としてはあるが，透明導電膜の 新規材料開発や成膜プロセス開発は今後の大きな課題になる と考えられる。

(Received April 26, 2013)

\section{文献}

1 ) S. Ishibashi, Y. Higuchi, Y. Ota, K. Nakamura ; J. Vac. Sci. Technol., A8, 1403 (1990).

2）樋口 靖, 石橋 暁, 太田賀文, 中村久三, 伊藤昭夫; DCマグネト ロンスパッ夕法によるITO膜の作製 (II) - スパッ夕電圧の影響 一, 応用物理学会学術講演会, (1988).

3 ) S. Ishibashi, Y. Higuchi, Y. Ota, K. Nakamura ; J. Vac. Sci. Technol., A8, 1399 (1990).

4）樋口 靖, 石橋 暁, 太田賀文, 中村久三, 伊藤昭夫; DCマグネト ロンスパッタ法によるITO膜の作製 $(\mathrm{I})-\mathrm{H}_{2} \mathrm{O}, \mathrm{H}_{2}$ 添加効果 - , 応 用物理学会学術講演会 (1988).

5 ) T. Yukawa, M. Takei, Y. Oono, A. Ota, M. Arai, J. Kiyota, S. Ishibashi, K. Saito ; Low Temperature Crystallization Technology of Extremely Thin TCO for Next Generation Panels, IDW'12 (2012). 